\title{
A Study on the Use of Action Learning in Korean Language Education as a Foreign Language
}

\author{
Hee-Eun, An \\ KOSIN UNIVERSITY, BUSAN, Republec of Korea \\ anheeeun@hanmail.net
}

\begin{abstract}
This study is to review the methods of developing teaching materials that can enhance educational effect when Korean instructors teach grammar to foreign students in Korean language education and to practice the methods. The grammar in foreign language education is an important region that expands the expression of meaning and enables exact communication, so instructors spend a lot of time instruction grammar. Nevertheless, the reality is that instructors in the Korean language field are still limited in the existing conventional grammar teaching through textbooks. This study practices the teaching materials that can draw interest of learners and instill positive recognition to them for prospective Korean language instructors by combining a specific teaching method called Action Learning. This trial is valuable in that it can extend to various instruction methods instead of the existing conventional methods in Korean language education, and that learners can improve effective language acquisition and communication ability.
\end{abstract}

Keywords: Korea language teachers, grammar education, action learning, Korean language education, teaching materials

Hee-Eun, An

KOSIN UNIVERSITY, BUSAN, Republec of Korea anheeeun@hanmail.net

\section{Introduction}

The foreign language education field today focuses on improving communication skills through interactions of learners. Especially for this, instructors have developed various teaching methods to escape restricted space and time. Due to this tendency, in the Korean language education as a foreign language, instructions based on communication are implemented continuously.

However, the various teaching methods and studies in the areas of speaking, listening, reading and writing are not actively done in the grammar area. Therefore, it is important that activity-based education to improve actual communication skill should be done in the grammar instruction of Korean language education. To solve this problem, instructors need to consider a learner-based educational alternative[1][2][3]. For the education of passive verb and causative verb, which make foreign students feel most difficult, the conventional grammar instruction stayed in the level of fragmentary vocabulary education. The main cause of this is textbooks that lack situational contexts. In the situation that learners need to study the contents of grammar and practice them in real life by themselves, the lack of knowledge in the textbook and lecture results in errors[4][5].

Therefore, this study applies the action learning technique to 'Korean Grammar Education Theory', which is a college lecture for prospective Korean language teachers who major in Korean language education as a foreign language in order for them to 
find the solution and to make and research teaching materials by themselves. The action learning technique is a process that learners organize teams, solve their own assignments or mutual assignments of team together, and learn the contents of assignments and solving process through knowledge acquisition, question and introspection. This technique helps not only instructors to improve their instruction skills but also foreign learners to acquire knowledge and to improve communication ability.

\section{Page Theoretical Background}

\subsection{Action Learning Definition And Characteristics}

The action learning is a method that small groups or individuals investigate actual business reasons and causes that they face, establish the action plan to solve the problems and apply them to the fields, and perform the learning process through the introspection of the practice process, or through repetitive and cyclical procedures by field application and introspection.

This can be considered as 'Just-in-time-learning' that can satisfy all demands of individuals, groups and whole organizations[6][7]. A. Toffler emphasized the importance of continuing learning by expressing an illiterate of the 21 st century is not the one who can't read or write but the one who has no ability to re-learn instead of discarding useless and obsolete knowledge among knowledge the he or she learned.' in his book Powershift(1992). This indicates that improving learning ability of individuals and organizations is the only method to cope with dynamic change.

Table 1 : Common and Differences Between PBL and Action Learning [6][8

\begin{tabular}{|c|c|c|c|}
\hline \multicolumn{2}{|c|}{ DIVISION } & ACTION LEANING & PBL \\
\hline \multicolumn{2}{|c|}{ BACKGROUND } & $\begin{array}{l}\text { Revans conducts group consulting } \\
\text { for miners in } 1054\end{array}$ & $\begin{array}{l}\text { Teaching and learning model } \\
\text { developed by Barrows in the } \\
\text { 1970s to improve the problems of } \\
\text { medical education }\end{array}$ \\
\hline \multicolumn{2}{|c|}{ COMMON GROUND } & \multicolumn{2}{|c|}{$\begin{array}{l}\text { Significant learning through learners' direct experience } \\
\text { Real problem solving } \\
\text { Self-directed learning } \\
\text { Running coaches and tutors are assistants, not content carriers } \\
\text { Improving problem-solving ability through team-oriented cooperation and } \\
\text { discussion } \\
\text { Emphasis on reflection according to learning process and results }\end{array}$} \\
\hline \multirow{4}{*}{ DIFFERENCE } & ASSIGNMENT & Real task & A practical problem \\
\hline & $\begin{array}{l}\text { PROBLEM } \\
\text { SOLVING }\end{array}$ & $\begin{array}{l}\text { Task } \\
\text { definition-Research-Suggestion- } \\
\text { solution-execution }\end{array}$ & $\begin{array}{l}\text { Problem Identification-Data } \\
\text { Collection-Learning Content } \\
\text { Sharing-Reconfirming Problems } \\
\text { and Deriving Solutions-Presenting } \\
\text { Problem Solving-Learning } \\
\text { Results and Presentations }\end{array}$ \\
\hline & HELPER ROLE & Running Coach $=$ Tutor + Courses & Tutor \\
\hline & GOAL & Problem solving + learning & learning \\
\hline
\end{tabular}


Table 2 : Six components and features of action learning [11]

\begin{tabular}{|c|c|}
\hline COMPONENT & CHARACTERISTIC \\
\hline ASSIGNMENT & Must be a real challenge that must be addressed in the field \\
\hline LEARNING TEAM & $\begin{array}{l}\text { Usually composed of 4-8 people, the overall ability level is similar. (Team assignments, } \\
\text { individual assignments, team + individual assignment) }\end{array}$ \\
\hline $\begin{array}{l}\text { WILLINGNESS TO } \\
\text { IMPLEMENT }\end{array}$ & If you find a solution to a problem through action learning, then you will apply it \\
\hline $\begin{array}{l}\text { KNOWLEDGE } \\
\text { ACQUISITION }\end{array}$ & $\begin{array}{l}\text { Awareness of the content of the task and the consciousness of the solution process } \\
\text { include problem solving process, communication, presentation, project management, } \\
\text { conflict management, meeting management, and learning operation. }\end{array}$ \\
\hline $\begin{array}{l}\text { REFLECTION AND } \\
\text { FEEDBACK }\end{array}$ & $\begin{array}{l}\text { Through the process of knowledge acquisition, the learning team reflects on itself and } \\
\text { receives feedback from the surroundings. }\end{array}$ \\
\hline RUNNINGCOACH & $\begin{array}{l}\text { Coaches need to introduce (understand AL, support decision-making, motivate), } \\
\text { progress (encourage atmosphere, identify reflections, highlight learning points, address } \\
\text { solutions, advise on meeting productivity, advise on how to proceed) In charge of } \\
\text { presentation preparation support and feedback) }\end{array}$ \\
\hline
\end{tabular}

The action learning emerges as 'Just-in-timelearning' that combines work and education, theory and practice, and education and business management in that education doesn't have to leave the working field, learning is done effectively in the process of actual business issues are solved, those who are well aware of the solutions of business issues and problems in the working field stay in the field, and planning and practicing are unified. This action learning is done in the voluntary and leading form by learners who are organization members as a real time learning experience. The optimum solution can be deducted as organization members who implement different experiences and tasks share various perspectives through team activity[8][9].

\subsection{Components And Execution Steps In Action Learning}

Revans[10], who is considered as a founder of the action learning, defined it by explaining the concepts that are irrelevant with the action learning. The difference between PBL(problem-based learning), which is used in the education field of Korea, and the action learning is in the table below.
In the action learning, learning is performed in the process that learning participants organize a team and solve the existential tasks by doing knowledge acquisition, questions and feedback, and introspection together. The action learning is a method that enhances self-directed learning ability due to the property of highlighting field atmosphere and actual task solution. It requires various competences such as cooperation of team members, collective intelligence, idea deduction, motivation, communication and problem solving ability.

\section{Korean Grammar Teaching Class In Action Learning}

\subsection{Action Learning Class Operation}

The researcher of this study is an instructor of a university located in Busan. 'Education plan based on the combination of action learning' is designed and implemented for 26 students (Korean language education majors and doble majors) who take the researcher's lecture 'Korean Grammar Educational Theory' during the second semester of 2019. 
The purpose of the lecture is to acquire knowledge and to seek instructing and implementing methods for grammar education in Korean language education as a foreign language. The classroom where the education was implemented was changed into the one for group activities of $4 \sim 5$ persons from the traditional classroom style (desks in a row facing the lecture desk). The education plan was designed for 2 weeks after the midterm examination. The action learning program was more effective when it is done for some sessions instead of the entire semester. Especially, 'passive verb' and 'causative verb' were the parts with action learning used among the grammar area.

The education of passive verb and causative verb for foreigners are taught in various forms through elementary and intermediate levels, and these parts, which are expressions that enhance understanding on Korean sentence structures, are considered as the most difficult. Therefore, foreigners are reluctant to use in real conversation situations. In addition, the textbooks for lectures cover passive verb and causative verb very simply, which is difficult to expect productive and effective lectures for instructors and learners because they suggest nothing but derivative passive vocabularies of '-이(i)/히(hi)/리(ri)/기(gi)/우(u)/구 (gu)/추(chu)'.

Therefore, this study has the participants design effective teaching plans for passive verb and causative verb, present concrete teaching materials and implement instructions. The next is the operation procedure based on action learning. To this procedure, the action learning theory of Revans is applied, and the actual education plan was designed by the researcher[12].

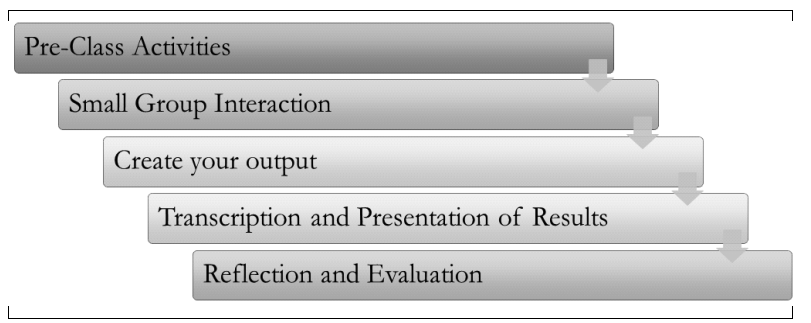

\section{Fig. 1 : Operational steps and procedures of Action Learning class}

\section{(1) Pre-Class Activities}

It is the stage that the lecture process, action learning and the method are understood before the lecture, and the lecture atmosphere is formed. Small groups are formed for action learning, and the theory of lecture is presented.

\section{(2) Small Group Interaction}

Problems are presented, and solutions for them are designed and planned. Students use action learning techniques such as sharing ideas, organizing thoughts and planning. Problems are presented based on deducted problems.

\section{(3) Create your output}

The actual outcome is produced through designing and planning by small group mutual activities.

\section{(4) Transcription and Presentation of Results}

In this stage, group members share their own opinions on problem solving. This method is used when problems are complicated or there are many opinions. In this stage, participants summarize and organize contents they need through group members' opinions. In addition, learners can improve their communication skills by sharing ideas with group members.

\section{(5) Reflection and Evaluation}

Participants introspect their learning attitudes and evaluate themselves. Participants can also evaluate their own understanding on learning contents. They evaluate lecture process with action learning techniques used, along with overall quality of lectures with action learning technique-based lecture stages included.

\subsection{Reality of Action Learning Training Plan}

The education plans are based on relevant lectures' textbooks, and the contents are disassembled and reorganized.

\section{(1) Pre-Class Activities}

The researcher showed the video of the lecture procedure, action learning class and the techniques with explanation before the lecture began. Small groups of 5 6 students were organized, and each group was arranged for easy mutual activities for learner-based lecture. Later, the text-based lectures were done with textbooks and PPT used, which enabled them to learn the background knowledge on 
'passive verb and causative verb'. Before the plans to educate this knowledge, learning motivation was prepared through mind map.

\section{(2) Small Group Interaction}

At the stage of small group mutual activity, the knowledge and background knowledge that the already learned were shared. After then, group members were had to improve their thinking ability and to establish solution methods by using action learning techniques through actual problems presented by the instructor.

\section{$<$ Problem presentation $>$}

"The passive and causative verb expressions are the most difficult in Korean grammar education, so
Korean language learners are reluctant to study in actual communication situations. Therefore, difficult and complicated sentences need education methods according to proficiency levels of Korean language learners. When passive and causative verb expressions are taught, it is necessary to devise and practice effective learning and teaching methods and data!”

The above matter should be implemented practically in the field as Korean language instructors. The education plans on passive and causative verb education plans and teaching materials are established. In this process, participants can expand thoughts on themes, and they can develop and practice original thoughts. Thus, each small group shared knowledge and data on passive and causative verbs and designed education plan.
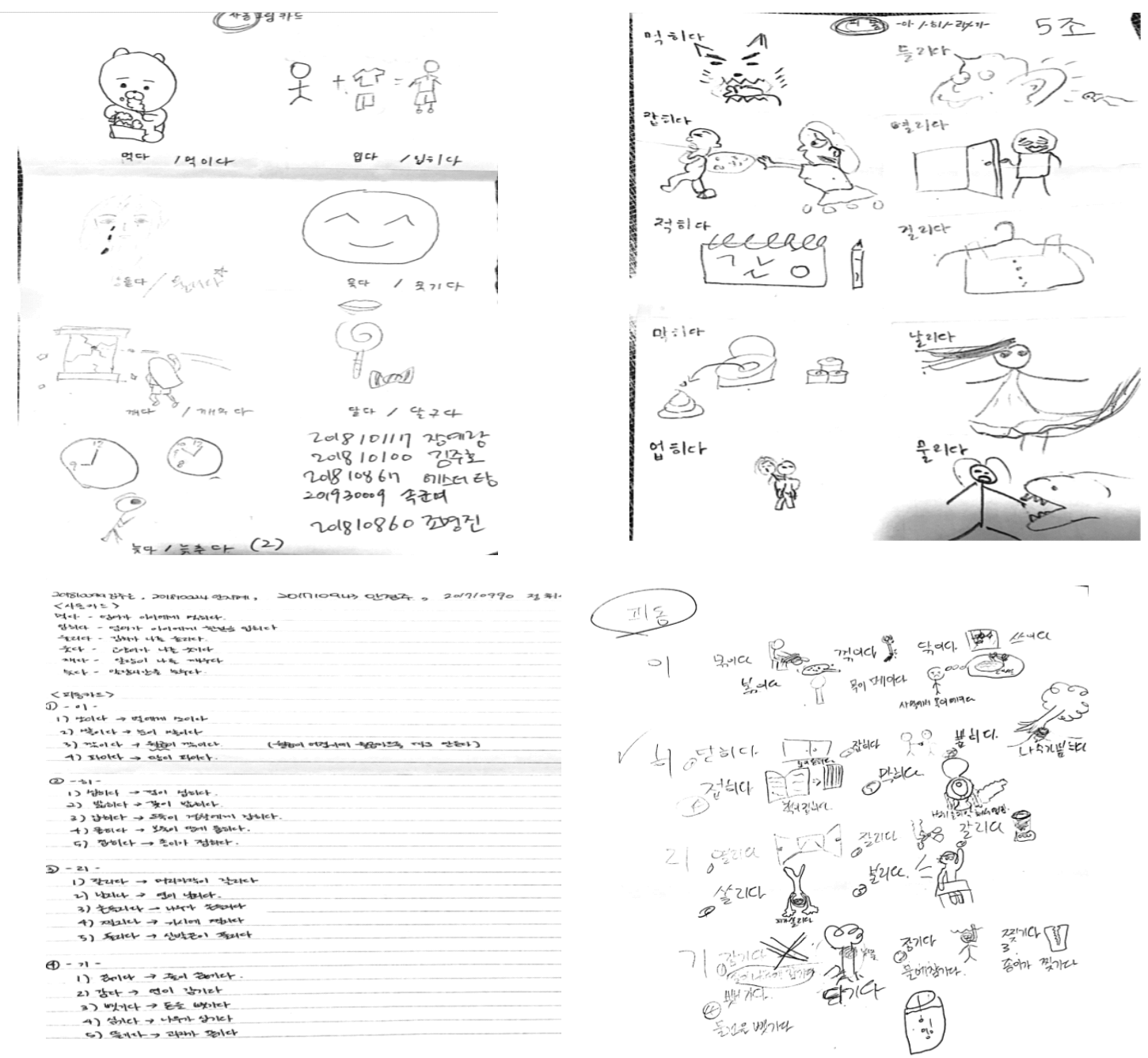

Fig. 2 : Small group interaction stage case 
(3) Create your output

In this stage, participants were had to practice the planned designed at the small group mutual activity stage right away. They made passive and causative verb teaching materials through pictures and photos out of classroom based on teaching plans and data decided at each small group.
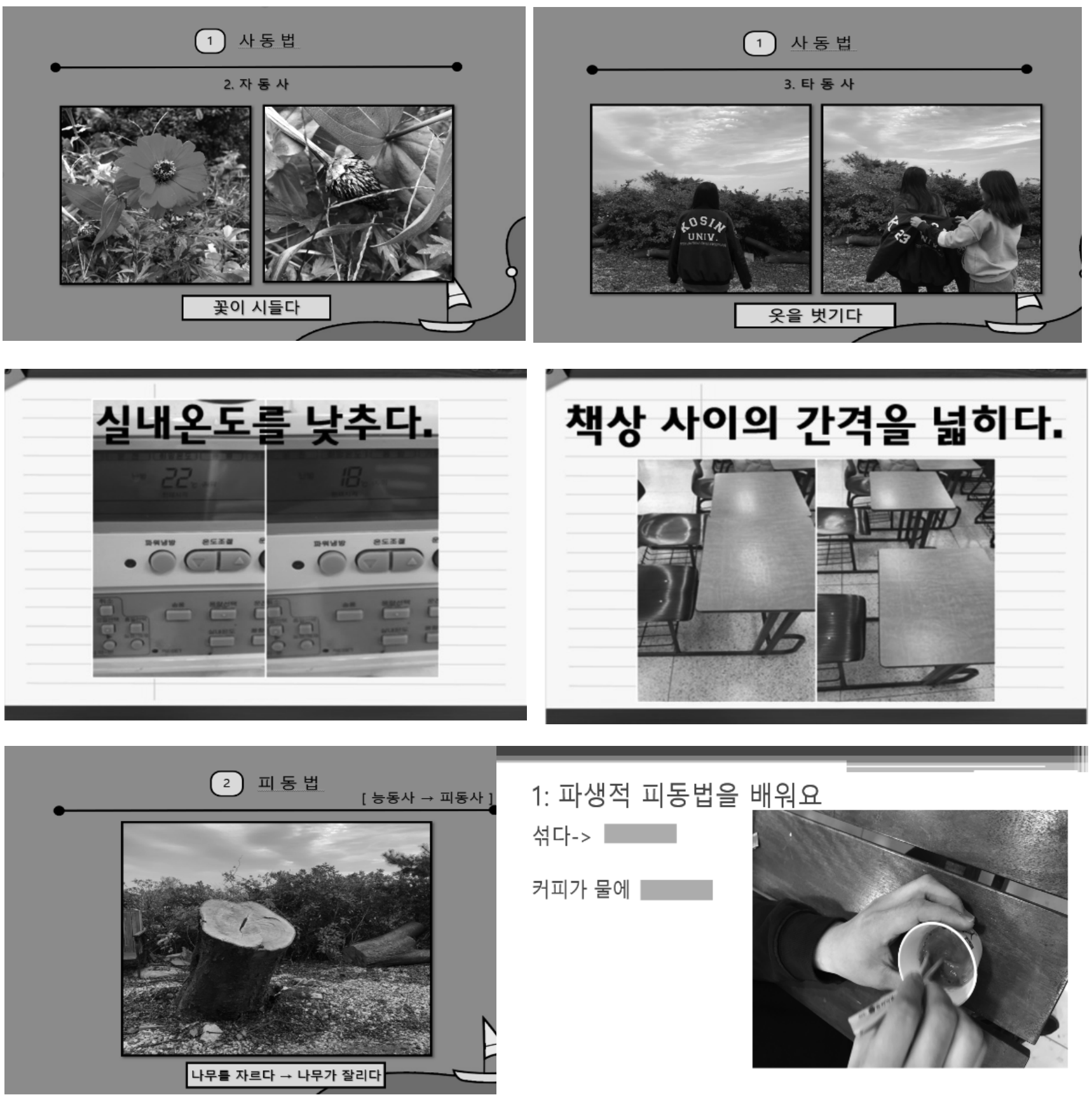

1: 파생적 피동법을 배워요 섞다->

커피가 물에

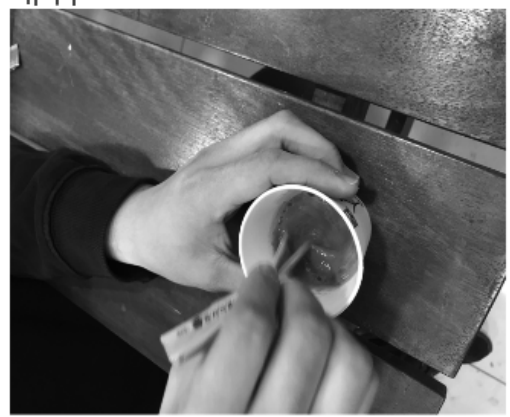

Fig. 3 : Example of producing results

(4) Transcription and Presentation of Results

This stage is for making presentations on teaching methods and materials about passive and causative verbs practiced before and for evaluating other groups. For evaluation, questions and answers were done on each group after presentation, and after presentation, strengths and weaknesses were discussed.

At this stage, group members shared their thoughts and reconfirmed the contents through others' advice, 
along with self-evaluation. In addition, the prepared materials became textbooks, and groups that were sitting became foreign students and those that made presentations became instructors. They experienced actual Korean language education.

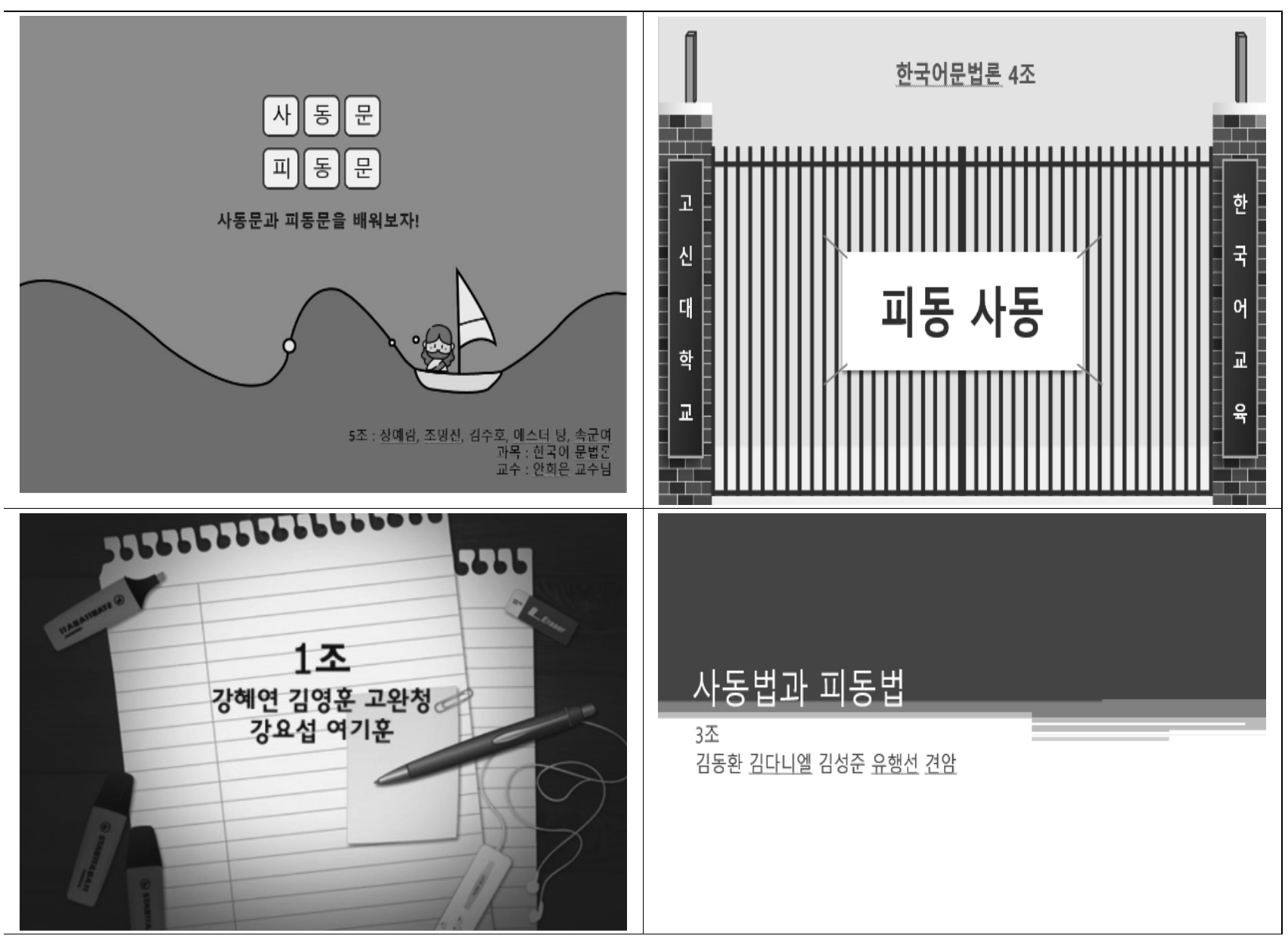

Fig. 4 : Examples of transferring and presenting results

\section{(5) Reflection and Evaluation}

After the lecture with action learning technique applied, the instructor's feedbacks about this activity were don for each group. After then, time for compensation and correction on presented data was assigned for each group. Lastly, participants were had to write brief summary of overall evaluation on the lecture with action learning techniques applied.

\section{$<$ Good point $>$}

"It is an interesting lecture where we could discuss and practice as a team instead of learning by sitting still." "The lecture was very fair because everyone had their own roles fairly." "I could learn others' thoughts through group activity, and older students who have more experience shared their information. It as also good that we could become closer." "I feel like I studied a lot more because students could think and solve problems by themselves instead of simply learning. I hope we could have more chances for this type oflectures."

\section{$<$ Bad point $>$}

"Too much assignment gave me hard time." "I felt pressured by the situations that I had to follow despite my passive personality." "This lecture gave a lot of assignment and had us make a lot of presentations, which look like another examination." "I didn't have enough time to plan, to make materials and PPT and to make presentation as a team activity. I hope we could have more time for those next time." 


\section{Conclusion}

This study is to review the methods of developing teaching materials that can enhance educational effect when Korean instructors teach grammar to foreign students in Korean language education and to practice the methods. Therefore, the action learning techniques were applied to the lecture 'Korean Language Grammar Education Theory'.

This trial is valuable in that Korean language instructors can expand their instructing methods broadly instead of limiting in the conventional methods, and Korean language learners can improve their language acquisition and communication ability effectively. Thus, the researcher of this study applied action learning techniques to Korean language education major students who take the lecture 'Korean Language Grammar Education Theory' at undergraduate course.

This lecture focused on designing, planning and practicing teaching plans and materials when undergraduate students who will become Korean language instructors teach at actual fields with the theme 'passive and causative verbs', which Korean language learners consider the most difficult in Korean language education as a foreign language. For this, stages of 'activity before lecture - small group mutual activity - producing outcome - displaying and presenting the outcome - introspection and evaluation' were practiced for two weeks.

The educational efficiency was confirmed in this project as participants could expand their knowledge and built their Korean language education experiences. Regarding the evaluation of participants, they mostly showed high satisfaction level in the lecture as they were interested in acquiring knowledge and participated in the lecture actively and smoothly through small group activities. However, some participants complained about too much assignment and lack of reflecting each student's level and preference. The limitation of this study was that it was conducted for only 26 participants, so the evaluation could be different according to personality and recognition of each learner if it is expanded to whole Korean language learners.

In the current early stage when the theory and practice with action learning applied are not done yet, this study can contribute to the academic world as a case study. Especially in Korean language education, foreign learner-based education and its research are done, so this study is expected to be a reference material for case studies of Korean language instructors' teaching materials. A follow-up study will extend action learning techniques to the whole areas of Korean language education such as grammar, vocabulary, speaking, listening, reading and writing and will implement specific education plans, along with detailed research and analysis.

\section{References}

[1] Kang Jong-Gu.An. "Interpretation on Special Education through Various Approaches". International Journal of Interactive Storytelling 1.2(2017): 19-24.

[2] Ho Kwon Kim. "Study on the Language Learning Device AR Puzzle and a Language Method Using Augmented Reality" International Journal of Computer Science and Information Technology for Education (2016): 79-84.

[3] Joo-eun Park. ".A Study on English Literature Teaching Methods Using Flipped Learning" .International Journal of Computer Science and Information Technology for Education. 1.1 (2016); 73-78.

[4] Lee Minkyoun, Cho Wwisu. " A Study on KFL Grammar Teaching Method Through Cooperative Learning - Based on JigsawIV" The Society Of Korean Language \& Culture Vol.0, no.65 (2019):.253-27.

[5] Choi Hae-ju. "Study on Effective Teaching Method of Passive and Causative ExpressionsFocus on Pedagogical Grammar in Korean Grammar Books and Textbooks and Errors of Korean Learners" New language education Vol.0No.78 (2008): 295-318.

[6] Marquardt, M. J., \&Revans, R. W. Action learning in action: Transforming problems and people for world-class organizational learning: Davies-Black Pub, 1999.

[7] McGill, I. \& Beaty, L. Action Learning, second edition: a guide for professional: management and educational development London: Kogan Page, 1995. 
[8] Rothwell, W. J.The action learning guidebook: a real-time strategy for problem solving, training design, and employee development: Pfeiffer, 1999.

[9] Spence, J. Action learning for individual and organizational development. Practice Application Brief. Columbus, OH: ERIC Clearinghouse on Adult: Career, and Vocational Education, 1998.

[10] Revans, R. W. Action learning: New techniques for management: Blond and Briggs Ltd., 1980.

[11] Marquardt, M. J. "Action learning and leadership. The learning organization" 7.5 (2000): 233-241.

[12] Hee-Eun, An. "A CASE ON KOREAN GRAMMAR EDUCATION USING ACTION LEARNING." International Journal of Education and Learning 9.1 (2020):29-34. 